\title{
A man with sudden loss of vision and ptosis
}

This article was published in the following Dove Press journal:

Clinical Optometry

6 March 2010

Number of times this article has been viewed

\section{Saroj Gupta}

Department of Ophthalmology, People's College of Medical Sciences and Research Center, Bhopal, MP, India
Abstract: A 49-year-old gentleman presented in our emergency department with sudden loss of vision and ptosis in right eye. He had type 1 diabetes mellitus for 10 years. His vision was reduced to perception of light and there was total ophthalmoplegia on right side. On investigating, signs of fungal rhinosinusitis were noted along with inflammation at orbital apex. The patient was treated with intravenous amphotericin B. Surgical debridement of sinuses was also done. The fungal hyphae were identified as Rizopus microsporum. The patient showed improvement in ocular signs at six weeks follow-up.

Keywords: visual loss, ptosis, rhinoorbital mucormycosis, paranasal sinusitis, orbital apex syndrome

\section{Introduction}

Acute visual loss may occur in association with paranasal sinusitis either as a complication of orbital cellulitis, optic neuritis, or as a part of the orbital apex syndrome. An infection from sinuses can easily spread to the orbit as they are very closely interrelated anatomically. The incidence of orbital complications secondary to sinusitis has been reported as between $21 \%$ and $90 \%{ }^{1-3}$ Early diagnosis and prompt treatment is important to prevent blindness. This case report describes a case of acute fungal sinusitis with orbital complications and the role of emergency surgical management.

\section{Case report}

A 49-year-old patient presented in our emergency department with sudden loss of vision with drooping of upper eyelid on right side (Figure 1). He had history of type 1 diabetes mellitus for 10 years. His blood sugar levels were high because he had stopped taking antidiabetic drugs three months previously. On examination, he only had light perception in his right eye whereas it was 20/20 in his left eye. Total ophthalmoplegia with III, IV, VI and $\mathrm{V}_{1}$ cranial nerve palsies on right side were observed. Magnetic resonance imaging of orbit and paranasal sinuses revealed mucosal thickening in ethmoid, maxillary, and sphenoid sinuses with signs of inflammation at orbital apex on the right side (Figure 2). Patient was immediately started on systemic antibiotics and antidiabetic drugs.

Radical debridement of affected sinuses was done on same day by an otolaryngologist. KOH-mounted tissue showed broad aseptate filamentous fungal hyphae. Culture on Sabourads dextrose agar demonstrated dense cottony fluffy
Correspondence: Saroj Gupta M-6 Windsor Estate, Phase II, Chuna Bhatti Kolar Road, Bhopal, Madya Pradesh, India Tel +9l 7552420999

Fax+91 7554005211

Email sarojini94@yahoo.co.in 


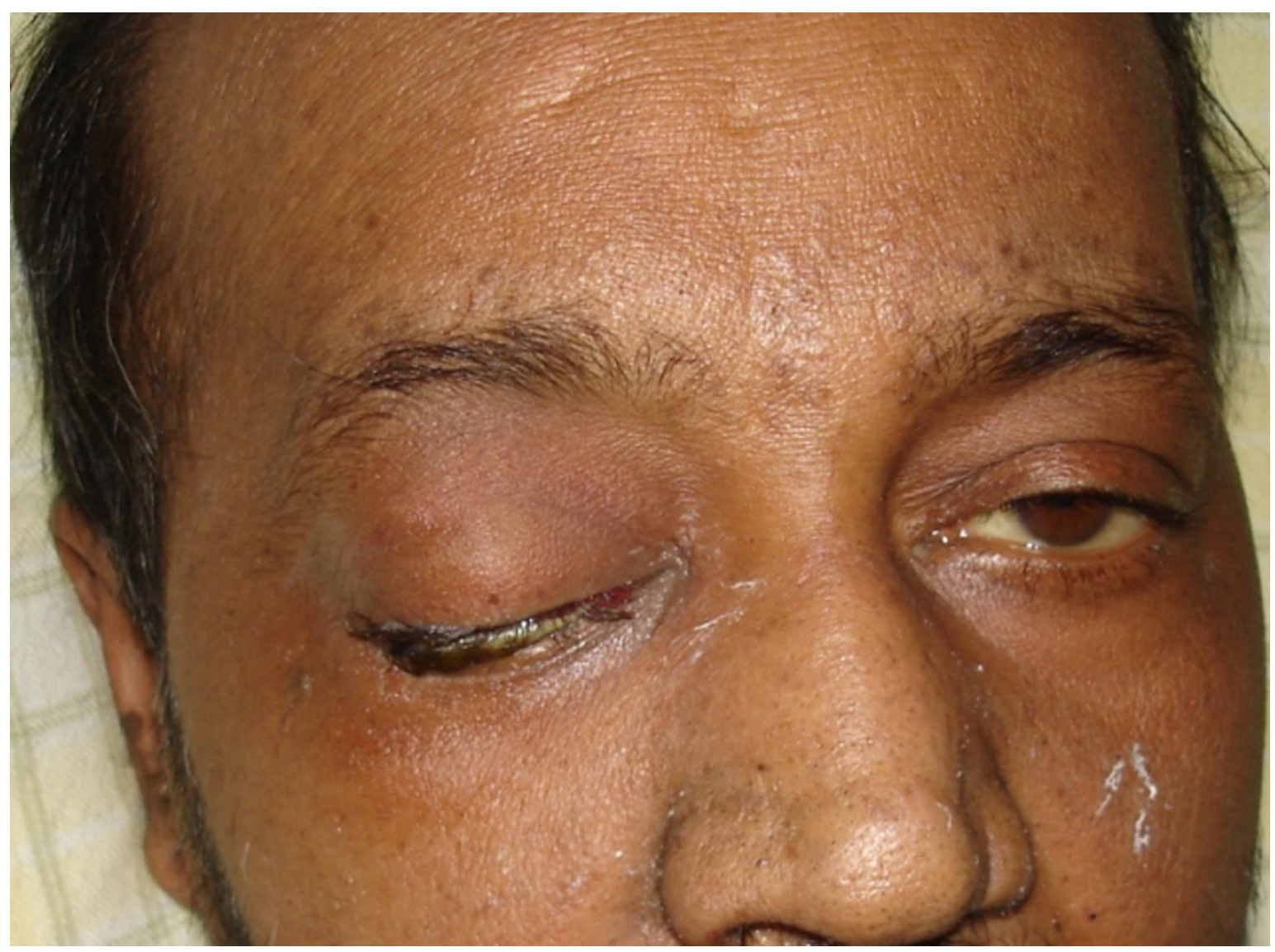

Figure I Clinical photograph of the patient showing ptosis on right side.

growth. Lacto phenol cotton blue mount of the fungus confirmed aseptate fungal hyphae with rhizoids and sporangia characteristic of Rizopus microsporum (Figure 3). Thus a diagnosis of rhinoorbital mucormycosis with orbital apex syndrome was completed. The patient was then put on intravenous amphotericin B $1.5 \mathrm{mg} / \mathrm{kg} /$ day for three weeks, then dosage was reduced to $25 \mathrm{mg}$ /day on alternate days for the next four weeks.

Blood sugars and renal profile were monitored. Improvement in ocular signs and symptoms was noted after about four weeks of therapy. Visual acuity improved to 20/200 at six weeks follow-up.

\section{Discussion}

Orbital involvement by paranasal sinus diseases is a well recognized entity. Infection from sinuses can spread either by direct extension through the bone or indirectly through valveless venous plexus surrounding the orbit and the sinuses. ${ }^{1}$ In fact orbital involvement is an emergency that threatens not only vision but also life from intra cranial complications.

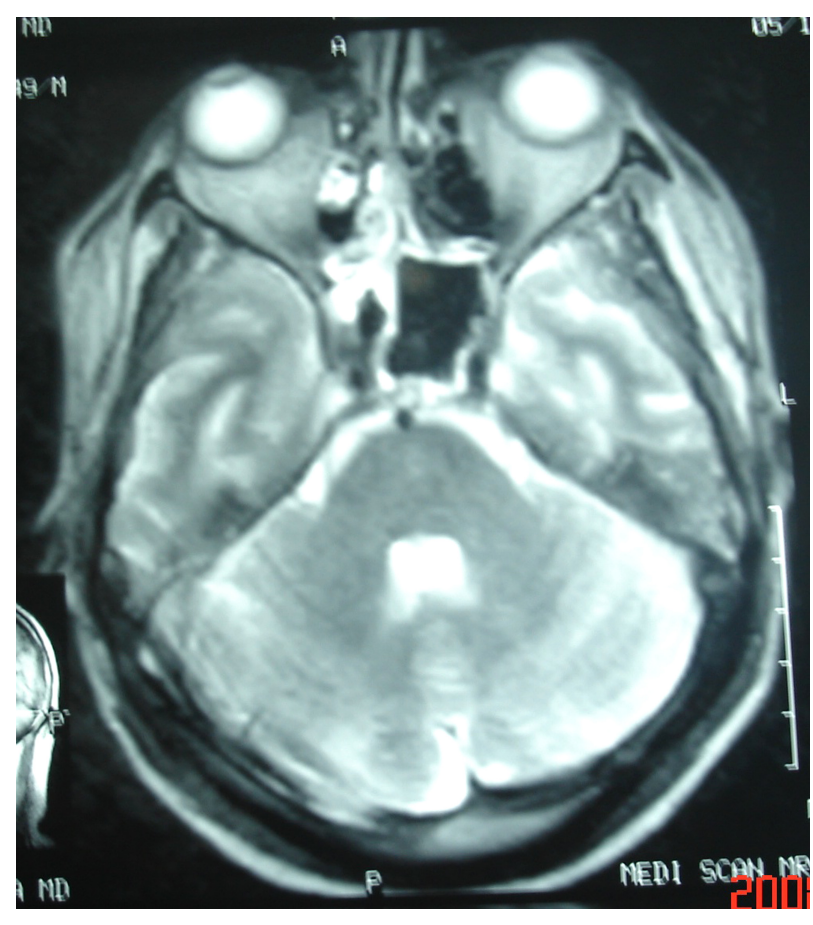

Figure 2 Magnetic resonance imaging of orbit and sinuses showing mucosal thickening in ethmoid and sphenoid sinuses with inflammation at orbital apex. 


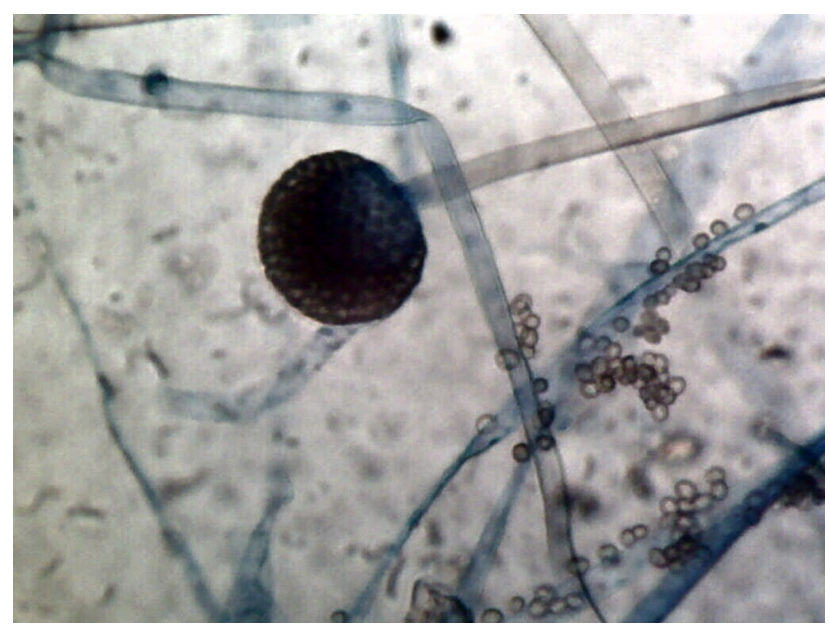

Figure 3 Lacto phenol cotton blue mount of the fungus showing aseptate hyphae with rhizoids and sporangia.

Rhinoorbital mucormycosis is an acute, fulminant, and fatal opportunistic fungal infection in humans. ${ }^{4}$ Uncontrolled type II diabetes and immunosupression are the common underlying causes. ${ }^{5}$ Diagnosis in early stage needs high degree of suspicion.

The conventional management includes control of diabetes, administration of amphotericin $\mathrm{B}$, radical debridement of sinuses, and orbital exentration. However there are increasing reports of success with limited or no surgical intervention in the orbit. ${ }^{4}$ We hope to report the same in this patient on subsequent follow-up.

Use of multiple treatment modalities allows completeresolution of orbital mucormycosis and spares the patients from blindness and disfigurement associated with exentration. ${ }^{6}$

\section{Disclosure}

The author reports no conflicts of interest in this work.

\section{References}

1. Lund VJ. The complication of sinusitis. In: Mackay IS, Bull TR, editors. Scott Brown Otolaryngology Rhinology. Edinburgh, UK: ButterworthHeimann; 1997:13:1-11.

2. Alia A, Kurlen M, Mathew S, Mathew J. Complications of acute infective rhinosinusitis: experience from a developing country. Singapore Med J. 2005;46(10):540-544.

3. Younis RT, Lazar RH, Bustillo A, Anand VK. Orbital infection as a complication of sinusitis: are diagnostic and treatment trends changing. Ear Nose Throat J. 2002;8(2):771-775.

4. Nithyanandam S, Jacob MS, Battu RR, Thomas RK, Correa MA, D'Souza O. Rhino-orbito-cerebral mucormycosis: A retrospective analysis of clinical features and treatment outcome. Indian J Ophthalmol. 2003;51(3):231-236.

5. Bhasali A, Bhadada S, Sharma A, et al. Presentation and outcome of rhino-orbital-cerebral mucormycosis in patients with diabetes. Postgrad Med J. 2004;80(949):670-674.

6. Pelton RW, Peterson EA, Patel BC, Davis K. Successful treatment of rhino-orbital mucormycosis without exenteration: the use of multiple treatment modalities. Ophthal Plast Reconstr Surg. 2001;17(1): 62-66.
Clinical Optometry

\section{Publish your work in this journal}

Clinical Optometry is an international, peer-reviewed, open access journal publishing original research, basic science, clinical and epidemiological studies, reviews and evaluations on clinical optometry. All aspects of patient care are addressed within the journal as well as the practice of optometry including economic and business analyses. Basic and clinical

Submit your manuscript here: http://www.dovepress.com/clinical-optometry-journal

\section{Dovepress}

research papers are published that cover all aspects of optics, refraction and its application to the theory and practice of optometry. The manuscript management system is completely online and includes a very quick and fair peer-review system, which is all easy to use. Visit http://www.dovepress. com/testimonials.php to read real quotes from published authors. 